\title{
Desired Sustainable Development Indicators of Commercial Enterprises
}

\author{
Olga Mustafina, Nadezhda Necheukhina *, Elena Makarova
}

\author{
Ural State University of Economics, Ekaterinburg, Russia \\ *Corresponding author.Email: nns@usue.ru
}

\begin{abstract}
The relevance of the paper is determined by research trends related to sustainable development of commercial enterprises. This issue remains in the center of interest of both business owners and the state. Sustainability of the national economy is closely connected with commercial enterprises' sustainable development. The authors concentrate on development of the most reasonable and actually required system of desired indicators for assessing sustainable development of commercial enterprises. The article discusses the category of "desired indicators of sustainable development" from different perspectives: scientific approaches of foreign and domestic scientists to the definition and concept of accounting and economic categories that have a direct impact on sustainable development indicators are analyzed; key points of desired indicators of sustainable development of commercial enterprises are considered; integrated assessment of potential for replenishment of commercial enterprises in terms of balance in resources, environmental conservation and social responsibility is given.
\end{abstract}

Keywords: sustainable economic development, reference point, commercial enterprise, revenues, expenses, system of desired indicators.

\section{INTRODUCTION}

Sustainability of economic development belongs to a relatively new research trend in economics and is of interest for the Russian economic community. Sustainability of the national economy is closely related to the sustainable development of commercial enterprises. This stems from the fact that any commercial enterprise is the primary element of the economic system, which is directly involved in the implementation of socio-economic objectives of the state by providing employment of the territory, payment of wages and tax liabilities. Therefore, assessment of sustainable development indicators of commercial enterprises is significant for both, the state and enterprise financial management as well as business owners.

In translation from French "repère" means a reference point or a starting point. The term «reference point", meaning "...indicators, on which the scale of measurements is based", has been borrowed from technical sciences. Nowadays the concept of "reference point" is widely used in the field of economics. At the same time there is no accepted opinion with respect to both, the concept of "desired indicators" and "desired parameters". In a general sense, the concept of "reference point" can be considered as the direction of the desired economic performance.

In accordance with article 50 of the Civil Code of the Russian Federation a commercial enterprise is a legal entity, which can be set up in the organizational and legal forms of business partnerships and societies, peasant (farm) households, business partnerships, production cooperatives, state and municipal unitary enterprises, pursuing profit as the main purpose of its activities. Consequently, the purpose of commercial enterprises is to increase profits. Therefore, it is clear that we can talk about "desired", which provide desired profit. Thus, desired economic indicators are indicators that characterize sustainable development of a commercial enterprise within the developed vector (direction) of achieving desired results.

\section{MATERIALS AND METHODS}

The study was conducted with the help of the following methods: analysis, synthesis, comparison, information grouping and generalization. Theoretical approaches to the study of desired sustainable development indicators with regard to commercial enterprises were considered. 


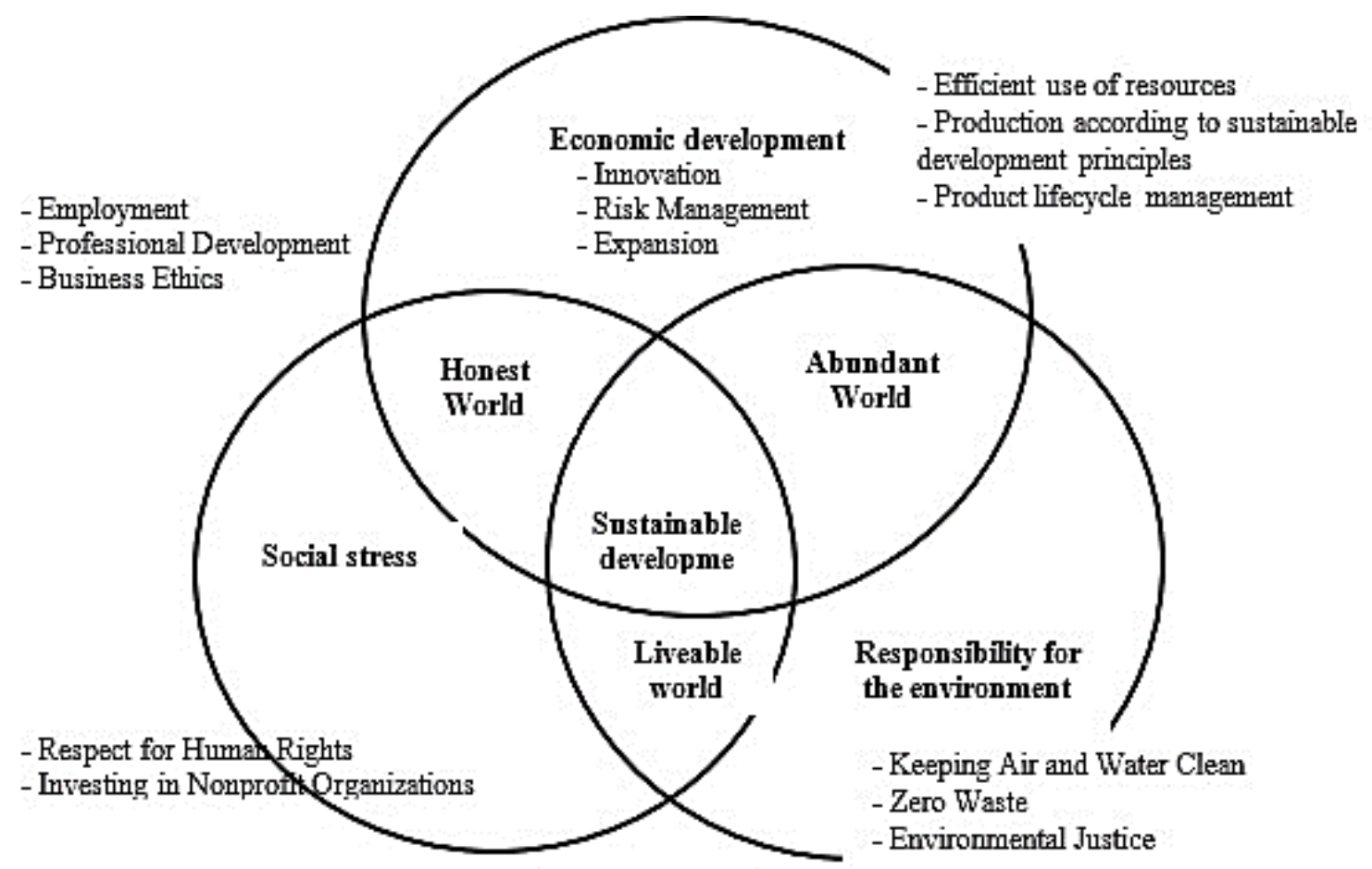

\section{- Healthcare \\ - Controlling Climate Change \\ - Preserving Biodiversity}

Figure 1 Model of Russian Federation sustainable development

In general terms sustainable economic development is a certain process of change, which is provided by the coherence of the exploitation of natural resources, investment direction, orientation of scientific development, as well as the development of the individual and the coherence of institutional change.

Sustainable Development Goals form the foundation for the Russian Federation's 2030 Sustainable Development Strategy, adopted by the international community on September 25, 2015. This is a new development framework that aims at transforming the world and will guide development at the global, regional and national levels. Initially, the model of sustainable development of the Russian Federation was presented in the composition of elements, which can be seen in Fig.1.

Accordingly, the basis for sustainable development of the Russian economy is maintenance of institutional, regulatory and macroeconomic conditions that act as factors determining the ability of economic systems to withstand external and internal pressures. This gives grounds to highlight the basic conditions for sustainability of the Russian economy, which are presented in Fig. 2.

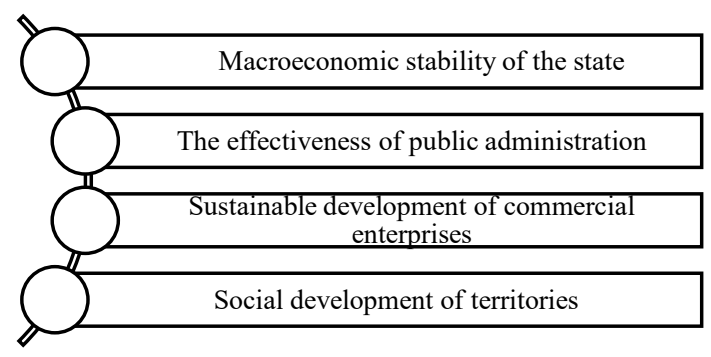

Figure 2 Conditions for ensuring sustainable development of macroeconomic system

Hence, one of the conditions for ensuring sustainable development of the macroeconomic system of Russia is the sustainable development of commercial enterprises. Therefore, it is necessary to characterize the basic elements that ensure sustainable development of commercial enterprises.

\subsection{The Study of Desired Sustainable Development Indicators for Commercial Enterprises}

The study of economic literature on the desired indicators of sustainable development shows that at present there is a lack of common understanding on the research area. Detailed study and analysis of different 
views allows to present various opinions on this issue. A.S. Rodionov has developed a scale of indicators, which is based on various approaches, presented in the works by F. Taylor (scientific management), A. Fayol (functional approach), M. Weber (rational bureaucracy). This scale represents a synergy of reference points and indicators that characterize sustainable development. Among the main parameters, according to A.S. Rodionov, are the following: 1) technology, which is determined by key resources, key activities and competencies; 2) structure of the main production factors, namely tangible and intangible assets and human resources; 3) competitiveness in a particular market niche, where any commercial enterprise is characterized by a certain technological mode and business reputation [7]. Therefore, the system of absolute and relative indicators (technical, economic, financial and nonfinancial) serves as a foundation for characterizing sustainable development of the enterprise.

According to A.V. Sidorin and N.S. Makarova "the system of desired sustainable development indicators should include: accuracy, adjustment and stability of management subsystems involving all the processes performed; indicator (indicators) of positive and stable dynamics of growth of economic indicators of enterprise activity; indicator of enterprise product competitiveness; indicator of consumer satisfaction; indicator of positive perception of enterprise by society (according to the estimates of the reputation, prestige of the enterprise); the indicator of the effectiveness of the mechanism to ensure the succession and reproduction of human resources of the enterprise; quality of employees' life indicators (considering material and non-material determinants)" [8].

M.E. Sokolov and Y.A. Pozdysheva in their paper "Reference points in the development of Russia's innovation system" propose division of desired sustainable development indicators into the following blocks: 1) finance; 2) human resources; 3) production base; 4) research base; 5) information and consulting base [9].

S.I. Lutsenko in his work "Desired indicators of corporate monetary policy" offers description of the main sustainable development indicators of a commercial enterprise, namely [10]:

1. Monetary assets management coefficient (monetary coefficient), which is defined as the ratio of cash plus short-term financial investments (cash holdings) to the value of total assets.

2 . Property security ratio or tangibility ratio, which is calculated as the ratio of fixed assets to the value of total assets.

3. Financial leverage ratio, which is defined as the ratio of the company's total debt to total assets.
4. Capital expenditures ratio. Calculated as the ratio of acquired fixed assets and intangible assets to the value of commercial enterprise's total assets.

5. Net working capital ratio, defined as the ratio of difference between current assets (minus cash and shortterm financial investments) and current liabilities to the amount of total assets.

According to L.D Revutskiy, modern economics has reached the level of specialized knowledge allowing to speak confidently about key sustainable development indicators of the commercial enterprises. The author considers the following indicators to be fundamental: 1) annual value added (annual conditionally net production); 2) annual net income (annual amount of wages and profits before taxes, fees and interest - annual net production); 3) annual profit before tax, fees and interest; 4) annual net profit [ 11].

Thus, desired sustainable development indicators of commercial enterprises represent a system of performance indicators, which allows to assess how rationally and effectively the resources of the enterprise are used in the process of achieving the strategic objectives of sustainable development. Anyway, despite the relevance of the issue under study, no common point of view on the system of desired sustainable development indicators of commercial enterprises has been established yet.

\subsection{Features and Characteristics of Commercial Enterprises' Sustainable Development}

The aim of sustainable development of the consumer market is to solve numerous problems and satisfy population's demand for a wide range of consumer goods and services offered at affordable prices within territorial accessibility with guaranteed quality and safety [12]. As it has been already noted, a commercial enterprise belongs to the list of primary elements in territory's sustainable development. Therefore, the conditions for sustainable economic development of the territory's belong to the strategic development goals, and demand the ability of rapid adaptation to constantly changing economic conditions. Modern commercial enterprises must meet the requirements for sustainable development, which, according to the authors, is reflected in the model of sustainable development of a commercial enterprise (Fig. 3).

The proposed conceptual model of sustainable development of commercial enterprises highlights the main levels of sustainable development as a complex integrated mechanism. This determines the novelty of the scientific approach. Sustainable economic development is characterized by the features which are formed as the result of interaction between multilevel system of economic relations and conditions of functioning, which 


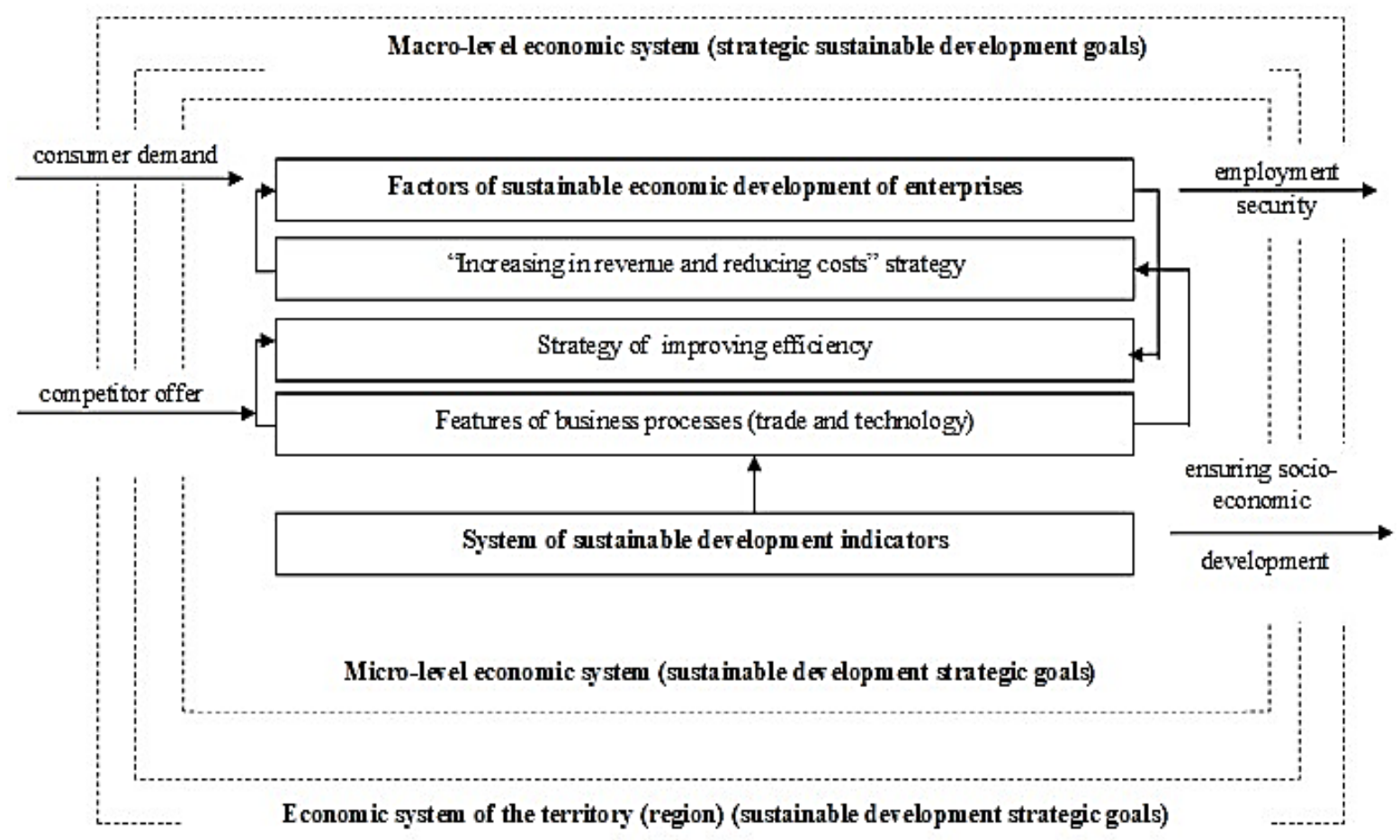

Figure 3. Model of sustainable development of commercial enterprises

in its turn is provided by individual elements. These elements are determined by the level in the economic system. As it can be clearly seen in Fig.3, a primary place in the proposed conceptual model is given to the commercial enterprise, which is the center and the basic element of territory sustainable development.

\subsection{Revenues and Expenses as Basic Components of Desired Sustainable Development Indicators of Commercial Enterprises}

The profit of a commercial enterprise is the result of the ratio of revenues and expenses. Revenues and expenses are fundamental accounting and economic categories, which have been the subject for debate and discussion for a considerable period. They are the main components of sustainable development of a commercial enterprise.

From the standpoint of accounting, economics, financial management and sustainable development, revenues and expenses occupy a central place in the mechanism of functioning and management of a commercial enterprise. Therefore, it is necessary to consider basic interests of business owners to the given accounting-economic categories that are determined by their financial purposes "...maximization of well-being of enterprise's owners in the current and perspective period, ensured by means of maximization of its market cost" [1].
Revenue is the source of existence of any commercial enterprise as without revenue "...there are no profits, without profits there is no enterprise...". In economics and accounting revenue is understood as"...the result of economic activity of the owner, ensuring the increase of his value..." [2]. At the same time, revenues are driven by expenses. Expenses are the costs incurred by a commercial enterprise in order to generate revenue.

Thus, revenues and expenses are primarily economic categories for the purposes of commercial enterprise's sustainable development, as they:

— "characterize the positive or negative flow of cash and other revenues per unit time" [3];

— belong to "...basic elements of accounting and analytical support of the enterprise, which are considered as accounting and economic categories in the system of management..." [4];

— belong to "...basic elements of financial reporting and basic categories of accounting" [5].

At the same time "...revenue is the most important factor of financial result, foundation for profit increase and, respectively, capital"; in its turn "...expenses are connected with generating profit and loss statement, and are aimed at identification of financial result... [6]".

The indicator of commercial enterprise's successful performance can be characterized by material wealth ensuring sustainable development. For assessment of 
material prosperity, ensuring sustainable development, the following methods can be used:

1. Assessment of a commercial enterprise on the basis of indicators of production costs or the current incoming value of receipts of nonmonetary assets, taking into account current discounted valuation of monetary assets minus the amount of capital raised.

2. Total retail sales including sales prices minus accounts payable.

3. Capitalization of the value of the net proceeds of monetary assets from retail sales of goods and related services.

4. Assessment of a commercial enterprise on the basis of current market prices referred to the total number of issued securities (shares).

Conducting assessment of commercial enterprises can also take into account prices change, which is caused by inflation. Thus, when developing a system of desired indicators for commercial enterprises' sustainable development this circumstance must be considered. Profit is a factor of increase in the value of capital, which also belongs to the list of desired indicators. One cannot but agree that all the factors affecting profit of commercial enterprises are also desired indicators providing commercial enterprise's sustainable development.

\section{CONCLUSION}

To summarize, it can be concluded that the key sustainable development indicator of a commercial enterprise is total profit, which demonstrates the change in equity, and is the factor of financial independence and financial risk. At the same time, being an independent category, profit supports business owners' welfare, as well as contributes to the strengthening of sustainable development of the territory economy and the state.

Revenues, expenses and profit, according to the authors, can be considered the key sustainable development indicators of a commercial enterprise. This conclusion is accounted by following:

1. Profit of a commercial enterprise is the result of commercial enterprise activity, which is generated as the result of creation of value added. At the same time profit is the main source of increase of equity capital. On the other hand, profit should be considered from the socioeconomic point of view, which allows us to say that profit is a desired indicator of sustainable development.

2. Revenues and expenses are necessary components of profit. Net profit assessment should always represent excess of revenues over expenses, but management practices can demonstrate lack of this ratio. Therefore, revenues and expenses are indicators that need to be monitored by staff accountants, analysts and financial managers.

Further research will be aimed at developing the concept of reporting sustainable development indicators of commercial enterprises. More research will be necessary since considering revenues, expenses and profit as the key sustainable development indicators for a commercial enterprise, requires introducing special reports, allowing their control and monitoring.

\section{REFERENCES}

[1] K. A. Humphreys, K. T. Trotman, The balanced scorecard: The effect of strategy information on performance evaluation judgments. Journal of Management Accounting Research 23(1) (2011) pp. 81-98.

[2] N.S. Necheukhina, O.V. Mustafina, L.N. Kuklina, Competitiveness of various segments of the regional consumer market. Regional Economy 14(3) (2018) pp. 836-850. DOI: https://doi.org/10/17059/2018-311.

[3] N.V. Maevskaya, Economic categories of "revenue" and "expense" in the accounting system. Innovative scientific research: theory, methodology, practice, 2017 pp. 98-100.

[4] N.S. Necheukhina, O.V. Mustafina, The genesis of accounting and analytical support for management of revenues and expenditures of economic agents in the retail segment of the consumer market. Scientific and Technical Bulletin of SaintPetersburg State Polytechnic University. Economic Sciences 11(2) (2018) pp. 70-80.

[5] A.I. Nechitaylo, Methodology and concepts of accounting: textbook. Phoenix, 2013 p. 221.

[6] A.B. Martínez, R.S. Galván, S. Alam, (2017) Financial Analysis of Retail Business Organization: A Case of Wal-Mart Stores, Inc. Nile Journal of Business and Economics 3(5) (2017).

[7] A. S. Rodionov, Seven control points of risk management-marketing. Actualscience, 2(5), pp. 78-81.

[8] A.V. Sidorin, N.S. Makarova, Model and functions of the management system of sustainable development of the enterprise. Modern research of social problems (electronic scientific journal) 4(12) (2012).

[9] M.E. Sokolov, Yu.A. Pozdysheva, Reference points in the development of the innovation system of Russia. Bulletin of Moscow Univ. Ser. 21 Management (State and Society) 4 (2010) pp. 128142. 
[10] S.I. Lutsenko, Reference points of corporate monetary policy. Contours of global transformations: politics, economy, law, 2015 pp. $70-81$.

[11] L.D. Revutsky, Production capacity, productivity and economic activity of the enterprise: evaluation, management accounting and control. Publishing house "Perspektiva", 2002 p. 240.

[12] E.B. Dvoryadkina, Economics of services in the conditions of digitalization: monograph. Publishing house of Polytechnic University, 2017 p. 807.

[13] A.N. Tsatsulin, A.V. Babkin, N.I. Babkina, Analysis of the structural components and measurement of the effects of cost inflation in the industry with the help of the index method, In: Proceedings of the 28th International Business Information Management Association Conference - Vision 2020: Innovation Management, Development Sustainability, and Competitive Economic Growth, 2016 pp. 1559-1573. DOI: https://doi.org/10.5862/je.240.3. 